\title{
Green Banking and Its Potentiality \& Practice in Bangladesh
}

\author{
Md. Omar Faruque ${ }^{1}$, Md. Nurul Kabir Biplob ${ }^{2}$, Md. Al-Amin ${ }^{3}$, Md. Sazzad Hossain Patwary ${ }^{4}$ \\ ${ }^{1}$ Department of Finance, Jagannath University, Dhaka, Bangladesh \\ ${ }^{2}$ Department of Finance and Banking, Begum Rokeya University, Rangpur, Bangladesh \\ ${ }^{3}$ Department of Business Administration, Dhaka International University, Dhaka, Bangladesh \\ ${ }^{4}$ Department of Finance and Banking, Begum Rokeya University, Rangpur, Bangladesh \\ Email address: \\ omar1212faruque@gmail.com (Md. O. Faruque), bip06651384@gmail.com (Md. N. K. Biplob), alaminjnu2012@gmail.com (Md. Al-Amin), \\ saz667@gmail.com (Md. S. H. Patwary)
}

\section{To cite this article:}

Md. Omar Faruque, Md. Nurul Kabir Biplob, Md. Al-Amin, Md. Sazzad Hossain Patwary. Green Banking and Its Potentiality \& Practice in Bangladesh. Science Journal of Business and Management. Vol. 4, No. 2, 2016, pp. 28-33. doi: 10.11648/j.sjbm.20160402.12

Received: February 9, 2016; Accepted: March 9, 2016; Published: April 6, 2016

\begin{abstract}
Banks are financial institution which can play an outstanding role between sustainable economic growth and environmental protection in order to prove themselves as environment friendly and socially accountable institution. For promoting this there is nothing but "Green Banking" which is the most talked topic in the recent banking activities and responsibilities. Green Banking refers to the banking business conducted in selected area and technique that helps the reduction of carbon emission surround the world. To aid the reduction of carbon emission bank should finance green technology and pollution reducing sectors. Green finance is an integral part of Green banking that makes a great contribution to the transition to resource-efficient and low carbon industries. Green Banking is certainly a new initiative throughout the world. The leading bankers and entrepreneurs have come forward to protect human being from environmental disasters. In the context of Bangladesh, if we think about it, we will find the situation to be terrible. Our people have little awareness about environment pollution and they do not understand the severe consequences of this pollution which will create an unexpected trouble in the coming decades.
\end{abstract}

Keywords: Green Banking, Green Finance, Environment, Corporate Social Responsibility (CSR), Online Banking

\section{Objectives of the Study}

Green Banking has some objectives and aims. Major important objectives of the study are as follows:

- To study the concept of Green Banking

- To identify the specific steps to adopt green banking properly

- To evaluate and estimate the green banking practices in Bangladesh

- To create awareness and importance of green banking among businessmen and general people

- To create new financial products and services that support environment friendly projects and industries which ensure environmental benefits.

\section{Research Methodology and Limitation}

The present study is analytical and conceptual in nature based on the secondary data. The secondary data has been collected from various newspapers, magazines, internet and commercial banks websites, Bangladesh Bank websites and reviews etc. Additionally, different working papers, journals and articles have been pursued enriching the literature of the study. To find out various green banking practices nationally and internationally, the websites of the respective banks have been utilized and studied. An intensive desk research has been undertaken to collect published data. The collected data are analyzed in the perspective of progress and adequacy of green banking activities in Bangladesh compared to the global endeavors. The major limitation of the study is that no primary data is involved in the study.

\section{Rationale of the Study}

In the age of global warming and climate change, delivering right services are not enough for clients but also practicing of green banking concept for friendly environmental issue as the corporate social responsibility (CSR) is inevitable to the target 
customer or clients and for sinking of global warming. Justification of the Study

Bangladesh is one of the least developed countries (LDCs) where natural calamities are a common phenomenon, which often causes huge losses. Even climate change impacts are high in our country, which needs proper dealing and management, effective guidance from all quarters, especially from banks. Green banks involve pursuing financial and business policies that are friendly to environment. The Bangladesh Bank has shown keen interest in it, and as such formulated guidelines in this respect, and encourages the scheduled banks to take measures to create a congenial atmosphere through 'green banking methodology'. Green banking can also reduce the need for expensive branch-banking and customer services.

$\mathrm{BB}$ advised all of the commercial banks to encourage their clients, from individual customers to real estate institutions to install solar panels on the roofs of their premises at their flat or building roofs. BB has also committed to pursuing low-carbon green development without compromising the imperative of faster economic growth and social development. The following suggestions will help us to mitigate the social costs and give us a positive NPV (Net Present value) from social angle:

Green Credit Cards: A green credit card allows a cardholder to earn rewards points which can be redeemed for contributions to eco-friendly charitable organizations.

Online Banking: Exercising an online savings and mobile banking you can play your part in green banking and ensure your contribution for the environment.

Paper-less Banking: Green Banking can reduce the excessive pressure on paper by providing electronic statements, paying online bills, fund transfer and so on which are the clear indication of environmental benefits.

Energy Consciousness: Developing energy- consciousness, using compact fluorescent lighting (CFL), giving emphasis on solar system can help banks save energy consumption considerably.

With a view to developing green banking practices in the country, BB formulated the "Green Banking Policy and Strategy framework" and "Environmental Risk Management Guidelines" in a consultative manner with several rounds of discussions with financial sector stakeholders, association leaders and technical experts. In response, many bank like NCCBL, Southeast Bank, AB Bank, Mutual Trust Bank, RAKUB, BRAC Bank, Trust Bank, etc. now finance environmental friendly projects.

BB is firmly committed to mitigate the reducing the effects of environmental degradation and ensuring sustainable economic development by issuing policies and guidelines for FIs to implement.

\section{Review of Related Literature}

Md. Maruf Ullah found that as one of the least developed countries Bangladesh is the worst sufferer of world environmental pollution through industrialization of the western countries. Under such extreme environmental threat, the financial sector of Bangladesh is playing a key role as one of the important stake-holders of the economy enforcing the businessmen/ industrialists of the country to design their various strategy/action plans keeping in mind the crucial environmental issues. Green banking (GB) is a component of the global initiative by a group of stakeholders to save the climate/environment. In this study it is tried to find out the present status of green banking practices. In doing so a comparative analysis has been initiated among different types of banks State owned Commercial Banks (SCBs), State-owned Specialized Banks (SDBs), Public Commercial Banks (PCBs) and Foreign Commercial Banks (FCBs)] in Bangladesh to see whether they adopted green banking policy guided by Bangladesh Bank (BB). The study concluded that only PCBs, FCBs have adopted green banking guideline and financed some of green based projects on the other hand SCBs and SDBs initiatives are not remarkable. Md. Touhidul Alam Khan wrote an article on Green Banking: Go green, Think green. In his article he said that "in a word, we can say that green banking refers to the attempt of the banking sector to consider social, ecological and environmental factors with an aim to protect the environment and conserve natural resources". The banking sector plays a major role in financing investment for commercial projects, which is one of the most important economic activities for economic growth. Hence, by taking various measures to save the environment, the banking sector can play a crucial role in promoting environmentally sustainable and socially responsible investment. As such, Green Banking is also known as Ethical Banking and Sustainable Banking.

The purpose of Green Banking initiatives taken by central bank is to ascertain required measures to save the environment and reduce pollution while serving or financing customers and improve in-house environment management through efficient and effective use of resources in all the branch and head offices of banks. Bangladesh Bank is well aware of the environmental degradation situation and has already given time-to-time directions to all scheduled banks. Commercial Banks are now required to ensure necessary measures to protect environmental pollution while financing a new project or providing working capital to the existing enterprises. Banks have been advised to facilitate their clients with utmost care financing for installation of Effluent Treatment Plant (ETP) in the industrial units and to finance in Solar Energy, Bio-gas, ETP and Hybrid Hoffman Kiln (HHK) in brick field under refinance program of Bangladesh Bank.

Green Economy is one whose growth in income and employment is driven by public and private investments that save the people. And the time has come for all lenders to "go green" and "think green" by setting their mindset taking remarkable footsteps through successful green banking initiatives. Khondokar Morshed Millat had a study on Green Banking in Bangladesh Fostering Environmentally Sustainable Inclusive Growth Process. They said that Bangladesh is perusing low-carbon green development without compromising the imperative of faster economic 
growth and social development. Development strategies of the Government of Bangladesh laid down in the perspective plan (2010-2021) and the Sixth Five Year Plan (FY 2011-15) declares clear commitment of pursuing sustainable growth. The country's vulnerability to floods, cyclones and to the threat of inundation of large coastal areas from global worming driven sea level rise makes sustainability a prime development concern.

Financial practices can crucially influence the speed of adaptation of environmentally sustainable output practices in the real economy. Aware of its responsibility practices in the financial sector, Bangladesh Bank, the central bank of Bangladesh, has spearheaded adaptation and promotion of green banking practices throughout the financial sector, towards safeguarding environmental sustainability. As a regular financial sector, the central bank already proceeded a long way in implementation green banking. Banks in Bangladesh have enthusiastically responded to Bangladesh Bank's guidance towards green banking, with steps in environmentally responsible financing that are beginning to make profound impact on environmental practices in the real economy.

The central bank issued policy guidelines for green banking on February, 2011. According to the guidelines, all operating banks and financial institutions need to take effective measures to conduct environment friendly banking activities in the country. Bangladesh Bank has also issued a common reporting format to all the commercial banks to report green banking activities including the extent of carbon footprint in a structured way. Banks and financial institutions now regularly submit a quarterly report to Bangladesh Bank on their performance of green banking activities.

\section{About Green Banking}

The term "green banking" generally refers to banking practices that foster environmentally responsible financing practices and environmentally sustainable internal process minimizing GHG emission.

Green Banking thus involves a two pronged approach. Firstly, green banking focuses on the green transformation of internal operations of all banks. It means all the banks should adopt appropriate ways of utilizing renewable energy, automation and other measures to minimize carbon footprint from banking activities. Secondly, all banks should adopt environmentally responsible financing; weighting up environmental risk of projects before making financing decision; and in particular supporting and fostering growth of upcoming 'green' initiatives and projects.

Reasons of practicing of Green Banking

The broad objective of the green banks are avoiding waste and giving priority to environment and society. Focusing on environment-friendly initiatives by providing innovative financial and ensure sustainable development.

- Using organizational resources with responsibility.

- Keeping the world livable for a long period of time.

- To minimize paper works as much as possible inside and outside the bank.

- To achieve cost and time efficiency.
Analysis and Findings of the study:

Bangladesh Bank selected ten commercial banks in Bangladesh on the basis of CAMEL'S rating and Risk Based Capital Adequacy (RBCA) measurement that are executing green banking practices. It is the first time of disclosing the green Banking report by central bank. Bangladesh bank also emphasizes on the environmental issue for launching new branch as well as selecting these banks such as Bank Asia ltd, Dutch-Bangla Bank limited (DBBL), Eastern Bank ltd (EBL), Islami Bank Bangladesh ltd, Mutual trust bank ltd, Prime bank ltd, Pubali Bank ltd, Standard Chartered bank, Shahajalal Islami bank ltd and Trust Bank ltd considering the green banking information till first quarter of 2012. The Bangladesh bank authority considered the following major activities under the green banking for getting the scenario of that:

- Green banking policy

- Green Banking unit

- Allotment of fund in green banking

- Funds for green financing

- Mobile banking

- Online banking

- Internet banking

- Green banking budget

- Environmental risk rating

- Effluent Treatment Plant (ETP)

- ETP related project

The above mentioned banks allotted Tk. 525 crore for green banking and Tk. 505 crore was provided for green financing among that fund. The 40 out of 47 nationalized and non nationalized commercial banks was established green banking unit. The 41 commercial banks was formulated green banking policies.

Source: Kaler kantho (21th June, 2012)

Policy formulation and governance:

Out of 47 scheduled banks, 40 banks have formulated their own Green Banking Policy Guidelines approved by their Board of Directors/Competent Authority while the rest 7 banks are yet to formulate their own policy for green banking.

Budget allocation : Banks have allocated Tk. 5252.07 million in their annual budget where allocation of (i) Tk. 5052.59 million for Green Finance other than financing the projects having ETP (ii) Tk. 194.35 million for Climate Change Risk Fund and (iii) Tk. 5.13 million by MTBL and DBBL for marketing and capacity building for green banking. Since projects having ETP fall under Green Financing, the total allocation of the annual budget for green banking in fact will be Tk. 10902.15 million.

Green banking unit/cell/desk: 43 banks have formed Green Banking Unit (GBU) for contributing to green banking activities while 4 banks are yet to establish GBU. Some banks have just started developing Strategic Planning for Sector specific Green Banking Policy.

Incorporation of environmental risk in core risk management (CRM):

Considering EnvRR is necessary in overall credit risk methodology as well as for computation of Adequate Capital under risk Based Capital adequacy and CAMELS rating under 
off-site supervision. Banks are now assessing EnvRR as per Environmental Due Diligence (EDD) Checklist of Environmental Risk Management (ERM) guidelines. As of March 2012, Environmental Risk Rating (EnvRR) has been done for 7165 projects and 6896 projects have been financed. The banks have disbursed Tk. 504557.61 million for these projects.

Bank's in-house green activities:

Some common In-house Green Activities reported by banks are as follows:

- Common use of table stationeries instead of individual use

- Use of paper on both sides for internal consumption

- Introduction of e-statement for customers instead of paper statements

- Use of online communication in the best possible manner

- Using more daylight instead of electric light and proper ventilation in lieu of using air conditioning

- Using energy saving bulbs and ensuring maximum utilization of day-light

- Use of Eco Font for printing light impression in both sides of the paper
- Setting defaults like thinking "twice before printing", "Printing only it really needs," "Please check your environmental responsibility" etc. in email correspondences

- Video/Audio conference in lieu of physical travel

- Conversion of Bank's vehicles (pool) into CNG and Use of energy efficient lights and other

- Electronic equipments

- Economic use of light and air conditioners

- Efficient use of printer cartridges, photocopy toner, office stationary etc.

- Sharing electronic files, voice mail and e-mail instead of paper memos

- Use of solar energy/Renewable energy sources

- More concentration on developing Green Office Guide for reducing information gap/reducing hazards/increasing efficiency/awareness/reducing pollution/developing Green banking for sustainable financing.

Green finance:

Banks have disbursed a substantial amount as Green Finance

Table 1. Category wise contribution of banks towards green financing.

\begin{tabular}{lllll}
\hline \multicolumn{1}{l}{ Category wise contribution of banks towards green financing } & & & \\
\hline Green Projects/ events & SCBs & PCBs & FCBs & SDBs \\
ETP & 77.68 & 3134.80 & 705.97 & 1.00 \\
Projects having ETP & 5758.47 & 122694.64 & 19726.55 & 0.00 \\
Bio-gas Plant & 28.31 & 219.76 & 0.00 & 0.00 \\
Solar/Renewable Energy Plant & 229.77 & 756.02 & 0.00 & 0.00 \\
Bio-fertilizer Plant & 0.00 & 4.50 & 0.00 & 0.00 \\
Hybrid Hoffman Kiln (HHK) & 112.40 & 795.17 & 0.00 & 0.00 \\
Others & 5249.70 & 5.20 & 220.00 & 0.00 \\
\hline
\end{tabular}

Source: Review of CSR initiatives of banks-2012

\section{Climate risk fund:}

Climate Risk Fund is required for precautionary measures for possible safeguards and mitigating hazards due to climate change. Climate Risk Fund may also be required for the banks as part of their CSR activities those relate to Climate Change condition. Banks are making effort to create a database on utilization of fund for their CSR activities those relate to Climate Change condition and also for the number of projects/events for possible safeguards and mitigating hazards due to climate change. 10 PCBs have allocated budget for Tk.194.35 million for Climate Risk fund.

Introducing green product:

Online banking
Substantial portion of internal works of the bank is done through online banking system-with outlook, e-mail. Access to online banking service for the customers is getting wider day-by-day.

Online banking scenario looks promising where 3042 number out of 7998 branches i.e. $38.03 \%$ are equipped with online banking services. 37 private and foreign commercial banks are fully automated ensuring online banking services in each of their branches. $89.05 \%$ of the total branches of PCBs have been brought under online banking coverage. In case of SCBs, $5.49 \%$ of the total branches have been brought under online banking coverage where Sonali Bank comparatively has a better scenario having $9.08 \%$ online coverage.

Table 2. Online banking coverage.

\begin{tabular}{llll}
\hline Online banking coverage & & \\
\hline Types/category of banks & Total No. of branches & No. of branches with online banking facilities & Percent branches with online banking facilities \\
\hline SCBs & 3442 & 189 & 5.49 \\
PCSs & 3078 & 2741 & 89.05 \\
FCBs & 63 & 63 & 100.00 \\
SDBs & 1415 & 49 & 3.46 \\
Total & 7998 & 3042 & 36.3 \\
\hline
\end{tabular}

Source: Review of CSR initiatives of banks - 2012 
Banks have started to concentrate on mobile and internet banking. $3.91 \%$ and $1.42 \%$ of the total number of accounts have been facilitated with mobile banking and internet banking respectably.

Mobile Banking: With fast expanding mobile telephone and great enthusiasm of the banks in offering financial services through mobile phones, Bangladesh Bank issued guidelines on mobile financial services in 2011. 23 Banks have been given license to provide mobile financial services (MFS) of which 14 banks have already started their operations. These banks are presently providing MFS to around 1.5 million customers; average transaction volume is around Taka 330 million per day. The average rate of growth of customer base in mobile banking is currently $15 \%$ per month. ATM services of Banks: Most of the banks have been offering 24 hours banking services through their countrywide ATM booths. Now 4,332 ATM booths are operating in Bangladesh. Dutch Bangla Bank is taking the leading position with installation of 2,170 ATM booths.

\section{Branches powered by Solar Energy}

Banks are introducing use of solar energy in their branches. 99 branches of 18 banks have reported installation of solar power panels.

Banks' in House Green Activities:

- Use of papers on both sides for internal consumption

- Introduction of e- statement for customers in lieu of paper statement.

- Use of online communications in the best possible manner.

- Using more daylight instead of electric lights and proper ventilations in lieu of using air conditioning.

- Using energy saving bulbs.

- Video /audio conferencing in lieu of physical travel.

- Conversion of bank's vehicles into CNG and use of energy efficient electronic equipments.

- Efficient use of printer cartridges, photocopy toner, office stationary etc.

- Sharing electronic files, voice mail, and e-mail instead of paper memos.

- Common use of table stationeries instead of individual use.

\section{Specific Findings}

- 45 banks have formulated policy for green banking.

- 46 banks have formed a Green Banking unit.

- 41 Banks have introduced a Green Office Guide.

- Environmental risk rating has been done for 13,779 projects.

- 13,833 risk rated prefects have been financed.

- 13, 07,479.64 million taka has been disbursed.

- 212 Branches and 150 SME Units/ATM booths are powered by solar energy.

- 37 banks are fully automated.

- 3226 branches have been facilitated with online coverage.

\section{Recommendations \& Suggestions}

- Government should carefully monitor and supervise the green banking practices in Bangladesh.

- Bangladesh bank must monitor the adherence of green banking guidelines by the commercial and non-commercial banks.

- Government encourages the general people about green banking awareness through the electronic and print media.

- Coordination among concerned authorities.

- Speeding up awareness and effective capacity building.

- Immediate concentration on sectoral lending policies and procedures.

- Shifting of different categories of industry (such as, garments, textiles, and tannery) to a proper location.

- Awareness of top management.

- Encouraging borrowers to go green.

- Need to apply green banking and use environmental risk management (ERM) guideline in efficient manner.

- Develop a culture within the organization based on environmental governance.

- Replicate global as well as local best practices.

- Share Knowledge and technical know-how with peer groups.

- Further integration with credit risk management in the overall credit risk methodology.

- Apply quantitative approach for environmental risk rating.

- Develop a database for technical assistance/issues.

\section{Conclusion}

Bangladesh is one of the most climate change vulnerable countries in the world. From the overall discussion, it can be said that green banking practices in Bangladesh are not at a satisfactory level. In line with global development and response to the global warming, Green banking plays significant roles. Government as well as every bank should take initiatives in respect of green banking practices for protecting our environment. Bangladesh bank will emphasize with significance of green banking activities/practices of a bank while according permission for opening new bank branches and approval for launching new bank. Government should also encourage the general people about the green banking practices. The central bank should monitor or supervise commercial banks whether they are practicing green banking or not. So, every bank has to participate and contribute to green banking practices in today's extreme national and global banking competition.

\section{List of Terms and Acronyms}

ETP - Effluent Treatment Plant

ERM-Environmental Risk Management

EnvRR-Environmental Risk Rating 
ATM - Automated Teller Machine

SCB - State owned Commercial Bank

PCB - Private Commercial Banks

FCB - Foreign Commercial Banks

SDB - Specialized Development Banks

SCBs $=$ State-owned Commercial Banks

CAMEL - Capital, asset, management, earnings, liquidity

RBCA - Risk Based Capital Adequacy

CSR - Corporate Social Responsibility

HHK - Hybrid Hoffman Kiln

SME - Small and Medium Enterprise

ICT - Information and Communication Technology

SRCC - Socially Responsible Corporate Citizens

\section{References}

[1] Millat, K. M. and Others 2012. Green Banking in Bangladesh Fostering Environmentally Sustainable Inclusive Growth Process. Http:

//www.bangladesh-bank.org/pub/special/greenbankingbd. (31 December 2012.).

[2] Green Banking Policy of BASIC bank ltd, Bangladesh, Head Office, Dhaka.

http://www.basicbanklimited.com/Green_Banking.php
[3] Atiur Rahman, "Financial Services at People's Doorstep", Governor, Bangladesh Bank, 2010.

[4] Bangladesh Bank (2011), Policy Guidelines for Green Banking. http://www.bangladeshbank.

[5] Policy Guidelines for Green Banking, BRPD Circular No. 02 Dated: February 27, 2011. Banking Regulation \& Policy Department, Bangladesh Bank, Head Office, Dhaka.

[6] Azam, Safiul (2012), Green corporate environment thru' green banking and 'green financing'. http://www.thefinancialexpressbd.com

[7] African Institute of Corporate Citizenship (2004), Sustainability banking in Africa, ISBN 0-620-32746-4.

[8] Md. Osman Gani, Green banking: Concept and policy guidelines (Monday, 29 July 2013; The Financial Express, Bangladesh).

[9] Md. Mustafizur Rahman, Md. Ali Ahsan, Md. Motahar Hossain, Meem Rafiul Hoq; Green Banking Prospects in Bangladesh, Asian Business Review, Volume 2, Number 2/2013 (Issue 4).

[10] Md. Shahid Ullah, Green Banking in Bangladesh: Progress, Problems and Prospects; Prajnan, Vol. XLIII, No. 1, April June, pp. 89-103. 